\title{
ISLAMIC COUNSELING FOR REDUCING THESIS PROCRASTINATION ON STUDENTS OF THE ISLAMIC GUIDANCE AND COUNSELING DEPARTMENT OF UIN SUNAN AMPEL SURABAYA
}

\author{
Amiatun Nuryana', Lukman Fahmi ${ }^{2}$ \\ ${ }^{1}$ Institute of Teacher Training and Education of Widya Dharma Surabaya \\ ${ }^{2}$ Sunan Ampel State Islamic University Surabaya \\ 1buananuryana@gmail.com, 2lukman.fahmi@uinsby.ac.id
}

\begin{abstract}
In this study, researchers will discuss the behavior that doesn't appreciate the time or called procrastination particularly in the case of students' academic procrastination in finishing their thesis. The target of this study is students of the last semester Islamic Guidance and Counseling Department in UIN Sunan Ampel Surabaya for the 2015-2016 academic year. In general, students have a study period of around 3.5 years up to 4 years. But not all students can finish their thesis on time. So, it makes an unrest effect on them. This occurs because it tends to delay their thesis. As a result, many students are unable to finish the thesis program within the specified time for their graduation. Therefore, there needs to be an effort to guide academic procrastination among these students. The Islamic Guidance and Counseling Department Program provides consultation, namely Islamic Counseling Guidance. The purpose of Islamic counseling guidance is to help students, so they do not give up easily in terms of facing their problems. Such as educational problems or personal problems (external or internal) and to help individuals maintain and develop good situations so as not to become a source of problems for themselves and others. The method used in this research is descriptive qualitative with a survey approach. This research refers to the problems or facts that occur. The technique of collecting data is by the survey, interview, and treatment.
\end{abstract}

Keywords: Procrastination; external problems; internal problems; Islamic Guidance and Counseling

\begin{abstract}
Abstrak: Dalam penelitian ini peneliti akan membahas tentang perilaku yang tidak menghargai waktu atau disebut dengan prokrastinasi khususnya pada kasus prokrastinasi akademik mahasiswa dalam menyelesaikan skripsi. Sasaran penelitian ini adalah mahasiswa Prodi Bimbingan dan Konseling Islam semester terakhir di UIN Sunan Ampel Surabaya tahun ajaran 2015-2016. Secara umum mahasiswa memiliki masa studi sekitar 3,5 tahun sampai dengan 4 tahun. Namun tidak semua mahasiswa dapat menyelesaikan skripsi tepat waktu. Sehingga menimbulkan efek keresahan bagi mereka. Hal ini terjadi karena tesis mereka cenderung tertunda. Akibatnya, banyak mahasiswa yang tidak dapat menyelesaikan program skripsi dalam waktu yang ditentukan untuk kelulusannya. Oleh karena itu, perlu adanya upaya pembinaan prokrastinasi akademik di kalangan mahasiswa tersebut. Program Departemen Bimbingan dan Konseling Islam memberikan konsultasi yaitu Bimbingan Konseling Islam. Tujuan dari bimbingan konseling islami adalah untuk membantu siswa agar tidak mudah menyerah dalam menghadapi permasalahannya. Seperti masalah pendidikan atau masalah pribadi (eksternal atau internal) serta membantu individu memelihara dan mengembangkan situasi yang baik agar tidak menjadi sumber masalah bagi diri sendiri dan orang lain. Metode yang digunakan dalam penelitian ini adalah deskriptif kualitatif dengan pendekatan survei. Penelitian ini mengacu pada masalah atau fakta yang terjadi. Teknik pengumpulan data dengan survei, wawancara, dan pengobatan.
\end{abstract}

Kata kunci: Penundaan; masalah eksternal; masalah internal, Bimbingan dan Konseling Islam 


\section{A. Introduction}

Student is someone who is registered and studying at a college. Students are prepared to become human resources capable of facing global competition, Students will become nation's hope, the one who bring their nation to globalization era. In the college for undergraduate or S-1, students must finish a thesis as a requirement for getting graduation. Students take a minimum study period of 3.5 years and the last requirement is a finishing thesis. But actually, there are many students can not finish their thesis on time. Sometime the students spent their study period around 4 up to 5 years. If they can't finish with that period, automatically, they will drop out from their college or that college give occasion to students for move to other college.

There are reasons that cause students procrastinate their thesis. As a result, many students are unable to complete their thesis within the normal timeframe for reaching graduation. So that the Islamic Guidance and Counseling Study Program UIN Sunan Ampel Surabaya's counselor give the support for those students to increase their motivation. Because it becomes college's responsibility and college has the full authority and rights in providing counseling services to these students. In accordance to a counselor's role in University, it is important for a counselor to have a strong based competency. Thus, the role of a counselor in University can be fulfilled optimally.

In psychology, the phenomenon of procrastinating or delay the work is known as procrastination, while the case of delay in this thesis can be defined as academic procrastination ${ }^{1}$. According to Tuckman in Utomo, procrastination is an inability to self-regulate which resulted in postponement of work which should be under the control of the person concerned ${ }^{2}$. Meanwhile, according to Wolter in Nugrasanti, academic procrastination is a failure to do a task within the desired timeframe or delay the task until the last moment. Actually, there are so many studies that has been conducted on academic procrastination, including a study by Fibrianti. Her research is about the relationship between parental social support and academic procrastination in completing undergraduate thesis. The results of this study indicate that the higher social support of the parents, the lower the academic procrastination in completing the thesis, and vice versa.

Procrastination is a problem that is often faced by every student in completing their studies. Therefore, it is important to create an effort to overcome academic procrastination among students. In this case, counseling approach is needed. The approach of guidance and counseling that has been highly developed nowadays, is based more from philosophical and scientific references which still show speculative and tentative tendencies (not necessarily, for a while, can change). For this reason, the researchers use the approach of Islamic guidance and counseling to improve the application of Islamic theories as reference to conduct counseling acts. Islamic guidance and counseling is an effort to help individuals learn to develop their nature or return to nature, by empowering faith, reason and human will which are gifts from Allah SWT. For us to follow His guidance and Muhammad the Prophet, so that we can develop properly and solidly according to the guidance of Allah SWT.

In this research, the researchers take the title Islamic Counseling for Reducing Thesis Procrastination in Students of the Islamic Guidance and Counseling Department UIN Sunan Ampel Surabaya. There are two purposes of the research; first, to know the level of the student's procrastination in Islamic Guidance and Counseling Department. Second, to know abaout giving counselor process in Islamic Guidance and Counseling Department. ${ }^{3}$

\footnotetext{
1 Irmawati Dwi Fibrianti. Hubungan antara Dukungan Sosial Orangtua dengan Prokrastinasi Akademik dalam Menyelesaikan Skripsi pada Mahasiswa Fakultas Psikologi Universitas Diponegoro Semarang. 2009$), 18$.

2 Danu Utomo.Hubungan antara Pemalasan Sosial dengan Prokrastinasi Akademik.2010, 2.

${ }^{3}$ Anwar sutoyo.Bimbingan dan Konseling Islam, Teori \& Praktik, ed. revisi.2009), 23.
} 


\section{B. Review Related Literature}

\section{Procrastination}

\section{a. Definition of Procrastination}

The term procrastination comes from the Latin procrastinate, from the word pro which means continue, to move, and crastinus which means tomorrow or to be next time. So, the word procrastination is delaying until tomorrow or preferring to do the work tomorrow. People who procrastinate can be called procrastinators. ${ }^{4}$ In other words, procrastination is an activity to postpone work until a certain time.

Some researchers have attempted to propose more complex definition of this procrastination behavior. Steel in Kartadinata \& Sia said that procrastination is "to voluntarity delay an intended course of action despite expecting to be worse-off for the delay", it means that procrastination is deliberately delaying the desired activity even though knowing that the delay could have a bad impact. This means deliberately delaying work even though it is known to have a negative impact.

According to Solomon and Rothblum in Surijah \& Sia, procrastination is a deliberate delay of work or completion of a task. ${ }^{5}$ From this definition, it can be seen that procrastination behavior is deliberate behavior, it means that the factors that delay the completion of the task come from the students itself. In short, procrastination is the act of delaying work even though the person were planning to finish the job. This procrastination behavior can be categorized as procrastination if it causes emotional discomfort such as anxiety or restlessness.

Tuckman in Utomo defines procrastination as an inability to organize himself which results in postponement of work that should be under the control of the person concerned. ${ }^{6}$ In other words, procrastination is a delay in work as a result of the inability to organize and control oneself.

Research conducted by Mc Cown as quoted by Ferrari et al in Irmawati found that procrastination was associated with a tendency to delay assignments and the time to do assignments. The delay is done because the act of doing the task is not in accordance with the predetermined intention, also because there is a delay in the intention to start the task. ${ }^{7}$ In short, procrastination is a person's tendency to procrastinate because it is against the intention that has been set. Likewise, with Mc Cown, Ferrari, Johnson, \& Mc. Cown also explained about academic procrastination which has many negative consequences and is an important issue that needs attention because it affects students themselves or for others and the environment in the form of less than optimal results.

As for the traits and characteristics of Academic Procrastination according to Burka \& Yuen that the characteristics of a procrastinator are, first, procrastinators tend to delay their work or tasks. Second, they think it is better to do it later than now because they are still busy or other reasons, and delaying work is not a problem. Third, keep repeating the procrastination behavior. The last, usually procrastination actors hesitate in making decisions.

From some of the opinions expressed by some of these experts, it can be concluded that procrastination is a person's tendency to procrastinate doing or completing the tasks ones currently facing which will ultimately result in anxiety because in the end ones cannot complete the task on time optimally or even fails to complete it.

Because this research was conducted on students who were in an academic environment, especially in the terms of doing their thesis, thus procrastination in this study was classified as academic procrastination.

\footnotetext{
4 Kartadinata \& Sia. "Prokrastinasi Akademik dan Manajemen Waktu," Anima: Indonesian Psychological Journal 23, no. 2 (2008): 110.

5 Surijah \& Sia. "Mahasiswa Versus Tugas: Prokrastinasi Akademik dan Conscientiousness," Anima Indonesia Psychological Journal 22, no. 4 (2007): 356.

${ }^{6}$ Danu Utomo.Hubungan antara ......, 2

7 Irmawati Dwi Fibrianti. Hubungan antara Dukungan Sosial ...., 29.
} 


\section{b. Factors Affecting Academic Procrastination}

In general, the factors that affect academic procrastination can be categorized into internal and external factors: 8

1) Internal factors, which can be described as the factors contained within the individual that affect procrastination, including:

a) The physical condition of the individual

Factors from individual that can influence the emerge of academic procrastination are physical conditions and individual health conditions, such as fatigue. According to McCown in Ferrari, someone who experiences fatigue, for example due to college or part time work, will have a higher tendency to procrastinate than those who don't. The level of intelligence one has doesn't affect procrastination, although procrastination is often caused by one's irrational beliefs. In other words, the physical condition affects someone to further delay his work and the level of one's intelligence does not affect him to procrastinate.

b) Individual psychological condition

Procrastination is often associated with individual perceptions of tasks -are those tasks fun enough to do, lack of motivation, how perfectionist is the person and the fear of failure. Several research results also found other aspects of individuals that also influence someone to have a tendency to procrastinate, including low self-control, external Locus of Control (LOC), low self-efficacy, and poor self-regulation.

2) External factors can be described as factors that came from the outside of the individual which caused procrastination, including:

a) Parenting

Based on the results of Ghufron's study, children's perceptions of the implementation of parental discipline had an effect on the level of adolescent academic procrastination. The study stated that the relationship between children's perceptions of the authoritarian and democratic approach of parents' parenting and the level of academic procrastination is opposite or negative. Which means, the more positive child's perception of the authoritarian and democratic parenting approach of parents, the lower the level of children's academic procrastination, and vice versa.

b) Education level

Education level can also affect procrastination. The tendency of students to procrastinate increases with the length of time they study at university.

c) Reward and punishment

Tasks that carry rewards are perceived as things that bring more joy than the ones someone's postponed. According to McCown and Johnson in Ferrari et al that perception can lead to academic procrastination. Besides the rewards obtained, academic procrastination also tends to be done on tasks that have punishment or consequences for a longer period of time than tasks that have consequences in the short time.

d) Too many tasks

Burka \& Yuen in Irmawati explained that procrastination occurs because there are too many task that should be done immediately. The execution of one task can cause other tasks to be delayed.

e) Environmental conditions

Environmental conditions where the level of supervision is low or less will cause a tendency to procrastinate when compared to an environment that is full of supervision.

\section{c. Types of Tasks in Academic Procrastination}

Solomon and Rothblum in Fibrianti suggest that academic procrastination occurs in six areas: ${ }^{9}$ First; Writing, which is the implementation of the obligations to writing tasks such as

\footnotetext{
${ }^{8}$ Irmawati Dwi Fibrianti. Hubungan antara Dukungan Sosial ......, 36.
} 
working on revisions. Second; Learning, including delays to face exams, especially in thesis, for example attending tutoring session with the lecturer. Third, reading, including delays in reading books or references related to the materials needed in the thesis. Fourth; Administrative tasks including returning library books, completing administrative requirements related to thesis. Last, attending academic meetings, such as postponing or skipping mentoring session.

\section{Islamic Guidance and Counseling}

\section{a. Definition of Islamic Guidance and Counseling}

The essence of Islamic guidance and counseling is an effort to help individuals learn to develop their nature, by empowering faith, reason, and freewill that are bestowed by Allah SWT. For us to follow His guidance and Muhammad the Prophet, so that we can develop properly and solidly according to the guidance of Allah SWT.10

From the definition above, we can conclude that Islamic Counseling guidance is a helpful activity because it helps individuals to learn about their essence as well as understanding and implementing Islamic guidance (Al-Quran and the Sunnah of His Prophet) so that they can be safe and surrounded by happiness in the world and the hereafter.

\section{b. Basic Islamic Guidance and Counseling}

According to Faqih in Murni, the basis of Islamic guidance and counseling is the Al-Quran and the Sunnah of the Prophet, because both are the source of all life sources for Muslims. It is from the Al-Quran and the Sunnah of the Prophet that the ideas, objectives and concepts of Islamic guidance and counseling are derived. Apart from the Al-Quran and the Sunnah of the Prophet, Islamic guidance and counseling used philosophy and science as the basis of it's study field. In this case, Qur'an Surah Ali-Imron verse 110 conducted that Islamic philosophy and science is in line with Islamic teachings. ${ }^{11}$ :

You are the best people who were born to humans, order the ma'ruf and prevent the unbelievers, and believe in Allah. If the People of the Book were believers, it would be better for them, among them there were those who believed, and most of them were wicked people. (Q.S. Ali-Imran [3]: 110).

Furthermore, the basis that comes from the Sunnah of the Prophet and Hadith can be interpreted as:

From Sa'ad Al Khudri ra. He said: I heard Rasulullah SAW say: whoever among you sees evil then let him prevent it with his hand (with power), if not able to do so, then with his tongue (admonition with advice, orally or in writing), if not able to do so then with his heart, the latter is the weakest faith.

From the description above, it can be concluded that Islamic guidance and counseling is part of the mission of da'wah ordered by Allah SWT that is oriented to invite, advise, and directing each individual to understand themselves and the life problems they face in a way or approach that is tailored to their abilities and psychological conditions.

\section{c. Purpose of Islamic Guidance and Counseling}

In general, Islamic guidance and counseling aims to help individuals manifest themselves as whole human beings in order to achieve happiness in this world and in the hereafter. The specific objectives of Islamic guidance and counseling are: first, helping individuals not to get problems. Second, helping individuals overcome the problems they are facing. Third, helping

\footnotetext{
${ }^{9}$ Ibid., 35.

${ }^{10}$ Anwar sutoyo.Bimbingan dan Konseling Islam, Teori \& Praktik, ed. revisi.2009.h.23

11 Murni Karyani. Pelaksanaan Bimbingan dan Konseling Islami terhadap Pelanggaran Tata Tertib Siswa Siswi Kelas Dua SMPN 2 Wonosari Klaten Jawa Tengah.2008. h.13.
} 
individuals maintain and develop good situations in order to stay good or become better so that they will not be a source of problems for themselves and others.

\section{d. Types of Islamic Guidance and Counseling Services}

Types of counseling guidance according to Prayitno dalam Murni Karyani, (2013) describe that counseling services have several types of services, ${ }^{12}$

1) Orientation Service

This orientation service aims to help clients to be able to adapt to a new environment. In other terms, so that someone can get the most from new things. This service will equip a person to gain experience and knowledge that they may never have had before. Meanwhile, the purpose of this orientation service is related to certain functions of guidance and counseling services. Like the function of understanding, orientation services aim to help a person gain an understanding of the various things that are important from the situation he has just encountered. If someone is able to adapt well and is able to make constructive use of existing resources in new situations, then the individual will be able to develop and maintain his or her potential. Effectively, the adaptation process also provides an opportunity to develop problem solving skills.

2) Information Service

Information service is a type of counseling service that allows a person to receive and understand knowledge about information that is trustworthy and can use the information obtained as material for consideration in making decisions for their attitude and behavior.

3) Potential placement and distribution services. It is a service that provides some act of potential, interests and talents channeling. It is also a service that allows someone to obtain a life placement according to their potential, interests and talents as well as their situations and conditions in order to achieve the goals they want to achieve.

4) Content control services. It is a type of counseling service that allows a person to develop good attitudes and behavior in learning, whether in religion, academic or life learning. In this content mastery service includes facts, concepts, processes, laws and rules, values, perceptions, reflection, attitudes and actions. This refers to the preventive function of Islamic guidance and counselling. Content control services aim to help individuals to prevent facing unwanted Problems

5) Individual Counseling Services

Individual counseling service is a part of counseling service that allows clients to have a face to face counselling session with the counselor in order to discuss and handle problems that ones face in life. This service aims to make clients understand the condition of themselves, their environment, and the problems they are experiencing.

6) Group Guidance Service

The group counseling is one of several types of counseling services that provides a flexibility for several groups (1-7) of human beings to have the same opportunity to gain equal access for counselling service related to problems they experienced through a dynamic and clustered atmosphere. The objective of Group Counseling is to explore the ability of establishing socialization that focuses on communicating skills with service members. Moreover, the flexibility of group guidance with the aim of motivating the development of views, understandings, impressions, knowledge and actions to support the manifestation of consistent behavior, namely increasing the ability to communicate both verbally and nonverbally.

\footnotetext{
12 Murni Karyani. Pelaksanaan Bimbingan ......,16.
} 


\section{7) Consulting Services}

Consulting services are one type of service in the field of counseling services that allows a person to consult to a consultant about the problems they face. In this service, clients have confidence in making decisions.

8) Mediation Services

Problem mediation service is a type of counseling service that is carried out by the counselor as an intermediary, liaison or judge for the benefit of two (or more) parties who are in a state of conflicts. They will be given the opportunity to do a mutual self-reflection in order to achieve positive and conducive relationship conditions between clients, or related parties.

9) Advocacy Services

Advocacy service is a service at the level of counseling, where someone gets help or a defense against unfair treatment. The aim is to protect the client's rights to get a fair treatment.

\section{e. Islamic Guidance and Counseling Function}

There are four functions of Islamic guidance and counseling, among others: First, the preventive function, which is to help individuals or prevent problems from arising for themselves. Second, the curative or corrective function, which helps individuals solve problems they are currently facing or experiencing. Third, the preservative function, which is to help individuals to make situations and conditions that were not good beforehand. And lastly, the developmental or development function, which helps individuals maintain and develop situations and conditions that have improved in order to stay good or get better.

\section{Research Methods}

This study will be conducted using a qualitative descriptive method with a survey approach. This research refers to problems or facts at this time. The descriptive nature of this research is aimed to explain about the procrastination act of students in the Islamic Guidance and Counseling Study Department generation 2015 who are working on their thesis at the Da'wah and Communication Faculty of UIN Sunan Ampel at Street Ahmad Yani 117 Surabaya.

1. Research Facilities and Infrastructure

There are the facilities needed in this research include; Firstly, Counseling room. Secondly, Communication equipment: telephone, handphone, etc. Thirdly, Counselor's journal, and the last, Counselor filing cabinets and files.

2. Data Collection Techniques

In this study, researchers collected data through by survey, interview, and treatment. Survey is conducted by using a questionnaire about procrastination adapted from the Tuckman Procrastination Scale to determine the level of thesis procrastination before and after getting treatment. Interviewing via WhatsApp and zoom, the researcher conducted an interview with Dr. Hj. Sri Astutik, M.Si and students to strengthen the data obtained from the survey. Treatment, related to the implementation of Islamic guidance and counseling for students of the Islamic Guidance and Counseling Study Program at UIN Sunan Ampel Surabaya who are completing their thesis.

There are some methods used in Islamic guidance and counseling to resolve the procrastination problem: First, Wisdom, using clear and firm words accompanied by arguments about procrastination that can confirm the truth and can eliminate doubts in students. Second, Lecture, by providing advice and instructions regarding procrastination in completing the thesis. Third, Discussion, by exchanging ideas with clients about the factors that support them to procrastinate their thesis and how to overcome them. Last, Social pressure, by creating a situation that can force the clients to work on the thesis, for example, creating a regulation that require clients to submit their thesis within a specified time. 


\section{Results and Discussion}

The results of the survey by interviews, academic procrastination of students in the 2015 Counseling and Islam Guidance Study Program who are still working on their thesis, at the Faculty of Da'wa and Communication are in the very low category with the category less than $20 \%$ because one batch is around 135 students, who have succeeded completed their thesis on time about 120 students, with the following categories;

Table 1. Academic Procrastination of Students

\begin{tabular}{|c|c|c|c|}
\hline No. & Number of Students & Percentage & Description \\
\hline 1 & $0-27$ & $\leq 20 \%$ & Very low \\
\hline 2 & $28-54$ & $21-40 \%$ & Low \\
\hline 3 & $55-81$ & $41-60 \%$ & Middle \\
\hline 4 & $82-108$ & $61-80 \%$ & High \\
\hline 5 & $109-135$ & $81-100 \%$ & Very High \\
\hline
\end{tabular}

From the table above, it can be explained that if the number of students is 135 , while those who experience procrastination are around $0-27$, it is in the very low category, because it is less than $20 \%$. If there are about 28-54 students, this is still in the low category. Meanwhile, those who are said to be in the medium category only reach 55-81 students and the percentage is 41$60 \%$. If there are 82-108 students out of a total of 132 students, this is categorized as high procrastination rate. For the highest level of procrastinate or a total of $81-100 \%$ if the number is around 109-135 students.

For students of the Islamic Guidance and Counseling Study Program, based on the table above, can be concluded that the self-awareness of students to complete their thesis on time is quite high where the University has successfully implemented a 3.5-year study program. But somehow this also needs attention. The study program is trying to solve the problem. So it is necessary to provide the right treatment to motivate them, so that they will not feel frustrated because they are left behind from their peers.

But previously the researchers tried to find out some of the causes of this problem. Based on the interview results, there are several reasons, such as economic factors, part-time working, programming the wrong study field or courses and being too active in extracurricular activities. Based on these factors some students participate more in campus activities so that they cannot manage time wisely. The inability of students to divide their time for work, socializing with their family or campus activities triggers failure in their studies at the end of the semester. It causes anxiety all the time which leads to depression and unended guilty feelings. It can damage the concentration to complete the final project. The Islamic Guidance and Counseling Study Program provides services in overcoming these behaviors.

There are several steps taken by the counselor in the BKI Department. The researcher interviewed Dr. Hj. Sri Astutik M.Si. which has provided several effective services for eliminating procrastination behavior. The first step is to motivate students to reduce activities that can take up student learning time. In addition, the counselor provides group guidance by utilizing group dynamics to obtain various insights, knowledge, skills, and values and attitudes that have a role to support in understanding and solving problems, so that they are able to develop themselves and benefit from activities.

Astutik as a counselor also tries to provide encouragement in environmental improvement, so that it can have a positive impact on these students. Motivate in improving the personal condition of the client. Improve students' abilities for a number of competencies that are needed in developing a mindset and responsibility. Encourage students not to do things that will pose a big risk, and to do something that is beneficial for their future. And the last is by building group support for the individual concerned. Instilling confidence in success, in this way she will be able to suggest optimistically to students about their success in dealing with a problem and reduce 
anxiety and worry in facing risks and instill discipline in learning. Eliminating pessimistic students in dealing with a problem they face.

Basically, in completing a task or work, you often experience difficulties, but if the habit of procrastinating a job is not something that should be followed. We often hear that every problem always has a solution, as long as we still have the willingness to make serious efforts to work on and put our trust in Allah SWT, we will definitely find it easy. The therapy provided by Dr. Hj. Sri Astutik, M.Si also crucified several verses of the al-Qur'an to touch their hearts. Like quoting Surat al-Inshirah verses 1 to 8, which reads;

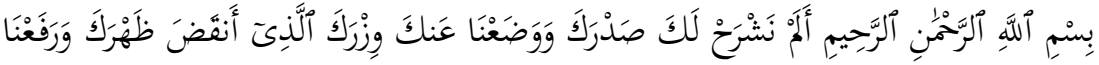

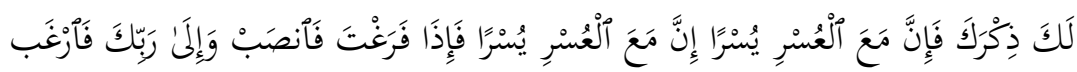

Have We not expanded for you your breast, And taken off from you your burden, Which pressed

heavily upon your back, And exalted for you your esteem? Surely with difficulty is ease. With

difficulty is surely ease. So when you are free, nominate. And make your Lord your exclusive object.

The meaning of surah al-Inshirāh verses 1-8 in the interpretation of al-Marāghỉy by Ahmad Mustafāa al-Marāghỉy states that in fact there are no insurmountable difficulties. If our souls are eager to get out of difficulties and look for solutions using the mind, namely by putting full trust in Allah, surely, we will come out and be saved from this difficulty. Even though various temptations, obstacles and obstacles come and go, but in the end, we will succeed in achieving victory.

With Islamic counseling given to them can be used as a conditioning in resolving their complaints. That is certainly related to the power of positive energy in solving the problem. However, it is not as simple as what it is looked like, because there are very fundamental factors related to clients as the target of Islamic counseling, among others, related to the development of potential (nature) in each individual who has a problem with the hope that in each individual with the problem can grow and develop in a sustainable manner. Ideal in every aspect which includes both physical dan spiritual, which always receives divine guidance.

\section{E. Conclusion}

Education is one form of effort in preparing students to increase their role in the future, and it is necessary to know that the development of the world is so fast, students should not be careless with these developments. So, to become a qualified human being and have a mindset that is in line with the advances of science and technology. Therefore, education has a very important role in preparing students to achieve success in the future.

Institutionally, guidance and counseling are very important parts of the world of education, both schools and colleges, which are aimed to providing assistance and facilitating students to achieve optimally programmed tasks. Every student needs help in learning how to solve problems in both lecture and lecture assignments, and has maturity in understanding the values of life. All students need to feel loved and appreciated, have a need to improve their abilities and academically and socially. They have a need to understand their potential. In this case a counselor is one of the mediators in charge of helping students who are experiencing difficulties or problems. As well as monitoring student behavior which includes disciplinary problems or academic procrastination. Procrastination by students can adversely affect their performance. The role of a counselor is very important to reduce procrastination. Therefore, a professional and competent counselor is needed in providing effective guidance and counseling services to students experiencing these problems. 


\section{References}

Sutoyo, Anwar. Bimbingan \& Konseling Islam Teori dan Praktik II. Yogyakarta: Pustaka Pelajar, 2014

Irmawati, Dwi Fibrianti. "Hubungan antara Dukungan Sosial Orangtua dengan Prokratinasi Akademik dalam Menyelesaikan Skripsi pada Mahasiswa Fakultas Psikologi Universitas Diponegoro Semarang." Skripsi. Semarang: UNDIP, 2009.

Kartadinata, Iven, dan Tjundjing, Sia. "I Love Tomorrow: Prokrastinasi Akademik dan Manajemen Waktu." Anima: Indonesian Psychological Journal 23: 109-119.

Karyani, Murni. Pelaksanaan Bimbingan dan Konseling Islami terhadap Pelanggaran Tata Tertib Siswa Siswi Kelas Dua SMPN 2 Wonosari Klaten Jawa Tengah, 2008.

Surijah, E. A. \& Sia, T. "Mahasiswa versus Tugas: Prokrastinasi Akademik dan Conscientiousness." Anima: Indonesian Psychological Journal 22, no. 4: 352-374. 